\title{
コールドスプレーの概要と 研究・開発の動向*
}

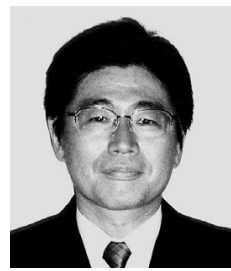

Overview of Cold Spray Technology and Trend of Its Research and Development ${ }^{*}$ by SAKAKI Kazuhiko ${ }^{* *}$

キーワード コールドスプレー, 溶射, 超音速流, 粒子積層, 低温プロセス

\section{1.はじめに}

溶射技術が開発されてちょうど 100 年の節目を迎え， 今年 5 月に米国シアトルで行われた国際溶射会議 (ITSC 2006) は “Celebrating the 100th year of thermal spray technology”として行われた。ここで紹介するコー ルドスプレー11は，このITSC 2006 においても最新の溶射 法として取り上げられ，最も注目されたセッションの一 つであった。

溶射は，粒子の加速・加熱に火炎，プラズマなどを使 用するが，コールドスプレーは高速微粒子衝突による表 面改質技術で常温から高々 $500^{\circ} \mathrm{C}$ 程度のガスにより加速 することが大きな違いであり，ある意味で粒子が溶けて いないので溶射には分類されないかもしれない。

本報では，最近，特に溶射の分野で新しい技術として 注目され，経済産業省の部材分野の技術戦略マップなど にも記載された2゙コールドスプレーの原理，最近の動向な どについて概説する ${ }^{3-6)}$.

\section{2.コールドスプレー技術の開発の経緯}

コールドスプレーは，図 1 に示すように材料粉末の融 点または軟化温度よりも低い温度のガス（作動ガス）を 先細末広形のラバルノズルによる超音速流にして，その 流れ中に材料粒子を投入して加速させ，固相状態のまま 基材に高速で衝突させて皮膜を形成する技術である。ま た，皮膜や基材に溶射法ほどの熱が加わらずかつ皮膜は 圧縮性の残留応力を帯びているため，数 $\mu \mathrm{m}$ から数十 $\mathrm{mm}$ 程度の厚膜が作製可能で，造形技術としても期待さ れている。

*原稿受付 平成18年 9 月5日

** 信州大学工学部 Faculty of Engineering, Shinshu University
コールドスプレーは，1980年代に入りロシア科学アカ デミーの西シベリアの拠点である Novosibrisk 研究所にて A. N. Papyrin 博士，A. P. Alkimov 博士らが研究開発を行 った．彼らは，この間の研究でコールドスプレーにとっ て大変重要な臨界速度，すなわち粒子を基材に衝突させ た際に粒子が皮膜を形成しはじめる衝突速度があること を報告している7)。この報告で図 2 に示すように銅，鉄， ニッケル，アルミニウムの粒子を銅基材に衝突させた際，

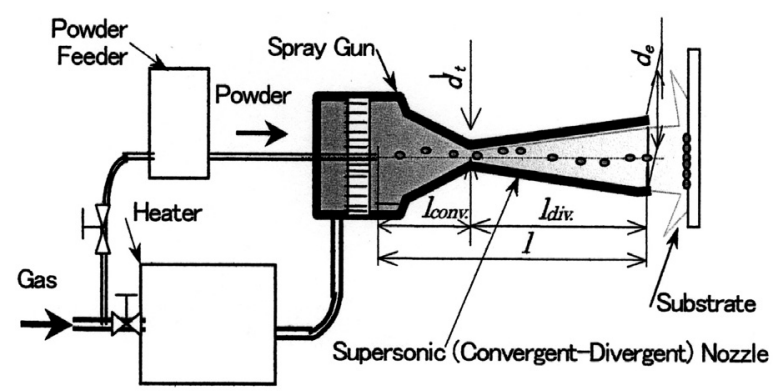

図 1 コールドスプレ一の概念図

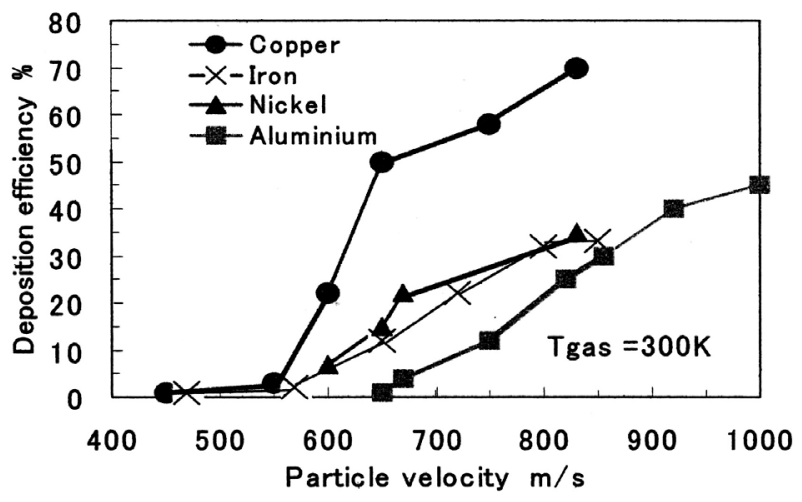

図 2 銅基材への粒子衝突速度と付着率の関係 ならびに臨界速度〉 
衝突速度が550〜 $600 \mathrm{~m} / \mathrm{s}$ 以上になると成膜しはじめ，銅 粒子においては約 $800 \mathrm{~m} / \mathrm{s}$ の衝突速度で $70 \%$ 程度の付着 率（供給した粉末のうち成膜する割合）が得られること を示している。これらの知見をもとに，彼らは特許を出 願し，1990年にロシア，1994 年にアメリカ合衆国1)で， 1995 年にヨーロッパで認可された。

その後，コールドスプレーは，ロシアのほかアメリカ とドイツを中心に研究開発がされた。さらに，国際溶射 会議 ITSC 2000 （モントリオール）前後から活発に研究さ れるようになり，日本，カナダ，英国，韓国，中国，才 ーストラリアなどでも研究が行なわれている.

\section{3. コールドスプレーの原理}

成膜のメカニズムについては，まだ十分に明らかにな っていないが, 精力的に研究が行われている. 前掲の図 2 に A. N. Papyrin 博士らの特許严を基筆者の考えている 概略図を示した。この特許のクレームの中では，コール ドスプレーを以下のように定義して，装置，ノズル形状 など具体的な記載はしておらず，いわゆる原理特許であ る.

「ガスと 1〜 50 $\mu \mathrm{m}$ の金属，合金，ポリマーまたはそれ らの混合物をジェットとして 300〜 $1200 \mathrm{~m} / \mathrm{s}$ の高速で吹 き付ける」

このコールドスプレーの原理を理解するために，次の プロセスに分けて考えるのが理解しやすいと思われるの で，以後これらに沿って簡単に説明する。

(1) 作動ガスの超音速プロセス

(2) 粒子の加速プロセス

（3）粒子の基材との衝突・変形・密着プロセス

（4）粒子の堆積・成膜プロセス

\section{1 作動ガスの超音速プロセス, 粒子の加速プロセス とノズル形状}

粒子を高速化するには，まず作動ガス自体が高速，す なわち超音速化しなければならない，ガスを超音速にす るには，図 1 に示すようにノズル入口部に所定の圧力と 流路に細い部分（スロート）をもつ先細末広ノズル（ま たは，ラバルノズルともいう）が必要である.

ガス速度 $U_{g}$ は，ノズル入口部のガスの温度，圧力を高 くすることにより大きくなり，さらに，ガス定数 $R$ が大 きいガスを使用すればより高速になる.

さらに，ノズル内のガス状態である圧力 $P$, 温度 $T_{g}$, 速度 $U_{g}$ は，ノズル形状により一意的に決まり，ノズル形 状が重要となる.

粒子の高速化には, ガス速度 $U_{g}$ を高くし, 粒子として は密度と粒子径が小さくいほうが有利である。しかし， 後述するようにコールドスプレーの場合，基材直前に衝 撃波（Bow Shock）があり，粒子径が数 $\mu \mathrm{m}$ 以下である とその衝突速度は急激に低下する ${ }^{8,9}$.

また，上述のヘリウムガスは密度 $\rho_{g}$ が小さいために粒 子の加速には不利であるが，それを補うだけの速度 $U_{g}$ が 大きいため, 結果的に粒子の加速にはへリウムガスが有 利である3,9)。ただし，ヘリウムガスは高価であり，分子 量が小さい分消費流量もかなり大きい.
図 3 に筆者が作動ガスを準一次元等エントロピー流れ と仮定して，コールドスプレーのノズル内における作動 ガスと粒子の状態に及ぼす作動ガス種の影響についての 数值シミュレーション結果を示す 3,10$)$. 同図よりヘリウム ガスは $100 \mathrm{~mm}$ の喉部以降の末広部で急激にガス速度 $U_{g-}$ He を列る一方で温度 $T_{g-\mathrm{He}}$ を急激に下げ，ノズル出口部 ではそれぞれ約 $2200 \mathrm{~m} / \mathrm{s} ， 140 \mathrm{~K}$ (静温度) となる．しか し, ヘリウムガスの密度が小さいため, 粒子速度 $U_{p-\mathrm{He}}$ は ガス速度に比べ急激には加速しないが, ノズル出口部で は約 $1200 \mathrm{~m} / \mathrm{s}$ に達する。

一方，空気は組成の $78 \%$ が窒素であるため，それらの 結果はほとんど差がないが，へリウムに比べガスと粒子 の速度はともにかなり低いものの, この条件で粒子速度 はノズル出口で臨界速度以上の $640 \mathrm{~m} / \mathrm{s}$ が得られる.

ところで，ガス種によらずガス温度がのど部以降の膨 張で水点以下まで低下するのに比べ, 粒子の温度はノズ ル内でガスより高くなっているが，これは粒子が固体で 熱容量があるためで, 他の溶射法にないコールドスプレ 一の特徴といえる。ノズル中心部のガス温度は膨張のた め低温になっていると思われる。ただし，実際のガス温 度では，ノズル入口部のガス温度にも依存するが管壁付 近は摩擦のため高温になっており，通常のスプレー条件 ではノズル表面温度は $200^{\circ} \mathrm{C}$ を超えている。

ノズル形状については図 1 に示す先細末広形が通常使
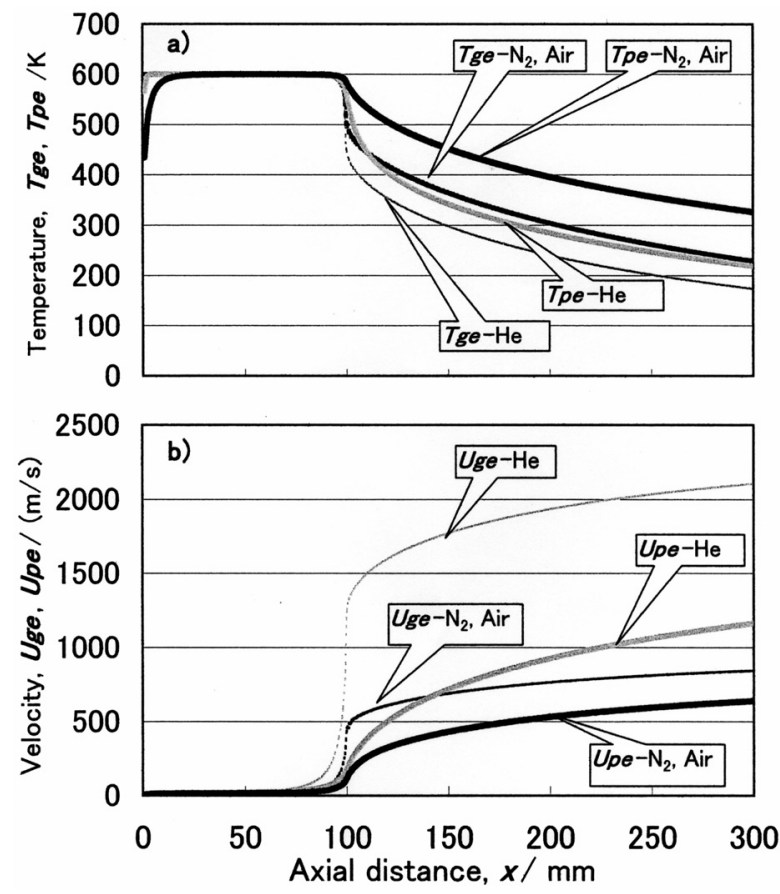

図 3 コールドスプレーにおける作動ガス種（窒素, 空気, ヘリウム）の影響3

a) ガスと溶射粒子の温度, b) ガスと溶射粒子の速度, $<$ 初期条件 $>$

ノズル形状寸法：先細末広（ラバル）形（全長 $300 \mathrm{~mm}$, のど径 $3 \mathrm{~mm}$, 出口径はノズル出口部に て大気圧になるようにガス種によって変えている) ガス：圧力 2.2 MPa [abs], 温度 $600 \mathrm{~K}$, 速度 $15 \mathrm{~m} / \mathrm{s}$,

粒子：Ni-Al 青銅 $(10 \mu \mathrm{m})$ ，温度 $300 \mathrm{~K}$, 速度 $5 \mathrm{~m} / \mathrm{s}$ 


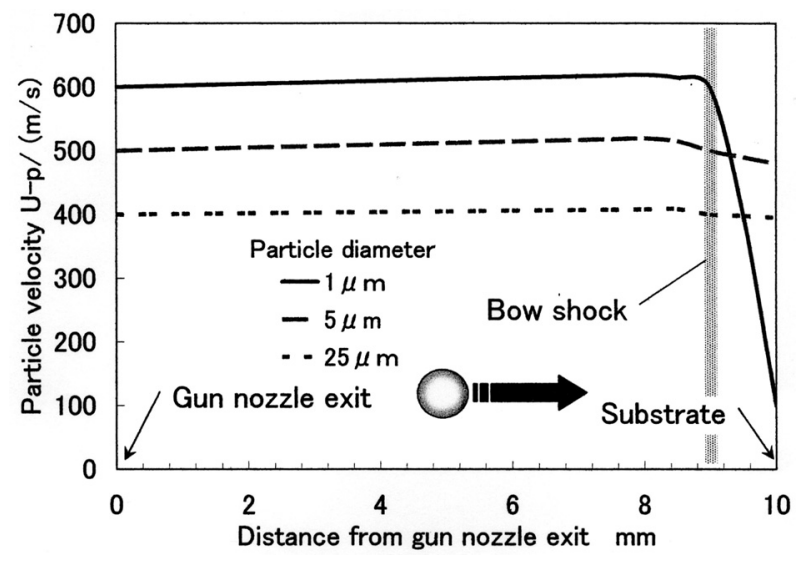

図 4 数值計算結果による粒子径の異なる粒子の速度に 及ぼす基材近傍の衝撃波の影響 [基材は $x=$ $10 \mathrm{~mm}$ に設置, 銅粒子, 作動ガス（空気, $\left.\left.27^{\circ} \mathrm{C}, 2.1 \mathrm{MPa}\right)\right]^{8}$

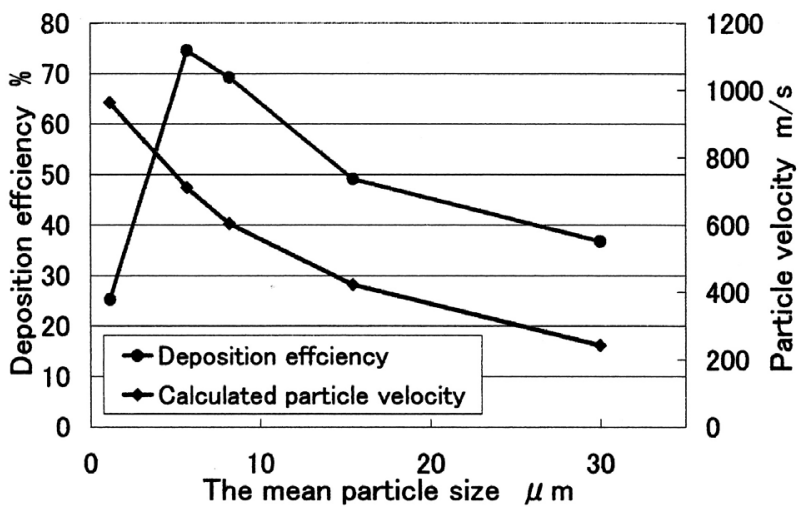

図 5 銅粒子の付着率及ぼす粒子径の影響（窒素ガス $\left.3 \mathrm{MPa}, 400^{\circ} \mathrm{C}\right)^{13)}$

（粒子速度は，ノズル出口部の計算結果）

用されているが，先細末広円筒形や先細円筒形などもそ れぞれの特徵があり，一部で研究されている11,12).

\section{2 粒子の基材との衝突・変形・密着プロセス}

(1) 粒子の衝突速度 コールドスプレーは，粒子が高 速で基材に衝突して，密着して皮膜を形成する。ここで， ノズルから噴出したガスは，大気中への拡散と摩擦のた め速度を下げてしまうので，これを防ぐためにコールド スプレーではノズル出口部と基材とが通常 $20 \mathrm{~mm}$ 程度と かなり近い位置にある。これは，コールドスプレーのガ ス温度が比較的低いので基材の加熱が少ないために可能 なことであり，コールドスプレーの特徴である。しかし， 基材が近いために， $600 \mathrm{~m} / \mathrm{s}$ 以上の超音速ガスジェット が急激にかつ不連続に減速（基材上のよどみ点で速度 $0 \mathrm{~m} / \mathrm{s}$ ） し，基材付近に衝撃波が生じる ${ }^{8,9)}$. よって，ノズ ル内でガスによって加速された粒子は，必ずしもその速 度のまま衝突せずに，粒子の慣性力が小さい場合には， この衝撃波により著しく減速される。図 4 には，基材付 近における粒子の減速状況を示す。同図から，ノズル出 口部では，粒径 $1 \mu \mathrm{m}$ が $600 \mathrm{~m} / \mathrm{s}$ と最速であるが基材直前 $1 \mathrm{~mm}$ 付近で急激に減速し，衝突時には $200 \mathrm{~m} / \mathrm{s}$ 以下にま で下がっているのに対し，粒子径 $25 \mu \mathrm{m}$ では，質量が大
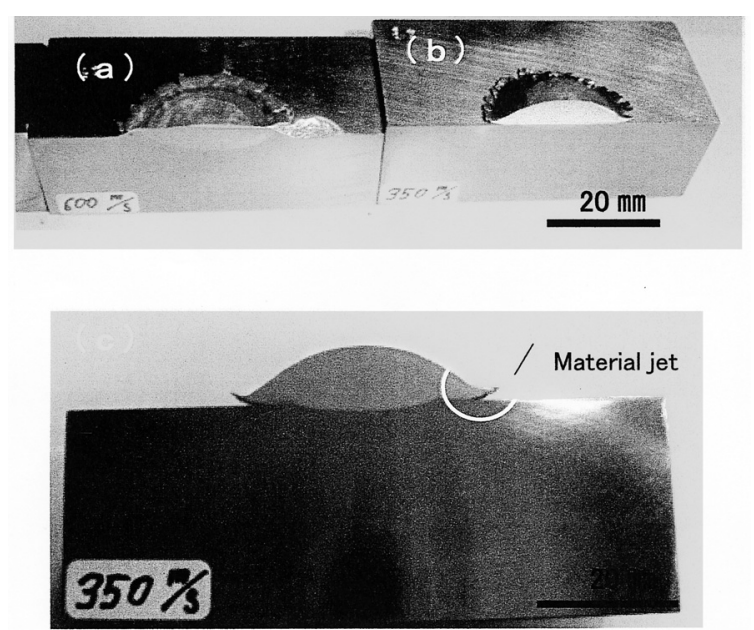

図 $620 \mathrm{~mm}$ 銅粒子の鉄鋼基材への衝突状況（衝突速 度 $350 \mathrm{~m} / \mathrm{s}$ ，ハンブルグ国防大の実験結果） (a)衝突速度 $600 \mathrm{~m} / \mathrm{s}$ 斜め上部から, (b)衝突速 度350 m/sの斜め上部から, (c)真横から見た切 断面の状態

きいためにノズル内での加速もあまりよくないが，衝撃 波による影響も少ない。図 5 は，銅粒子の付着率に対す る実験結果である．銅の粒径が小さくなるにつれて，粒 子の衝突速度が高くなるため付着率も上がり平均粒径 $5 \mu$ $\mathrm{m}$ でピークの $75 \%$ に達し， $1 \mu \mathrm{m}$ では急激に低下してい る13. よって，大気中でコールドスプレーを行うには，使 用する粒径には下限があり，粒子の密度にもよるが，数 $\mu \mathrm{m}$ 以下の微粉では不適正であることが報告されてい $b^{14)}$.

(2) 密着, 臨界速度 前掲の図 2 に示したようにある 粒子の衝突速度（臨界速度）以上になると粒子が付着 · 堆積しはじめる.この臨界速度の理解として，いくつか の研究グループが報告している.

図 6 にコールドスプレーの粒子の衝突状態を確認する ため, $20 \mathrm{~mm}$ の銅粒子を機関砲でステンレス鋼板に衝突 させた様子を示す．粒子の端部にはともに Material jet と 呼ばれるひだ状に広がる粒子の一部が観察される。これ は, 数 $10 \mu \mathrm{m}$ のコールドスプレーの場合でも確認されて いる. 粒子の変形は, 基材との界面付近でせん断変形し ているのがわかる.

M. F. Smith 博士らの研究グループは，粒子と基材が金 属同士の場合，以下の因子があると報告しているが，臨 界速度の十分な理解には至っていない20-23).

(a) 粒子と基材の密度，弾性率，音速

（爆着モデルの場合・・・臨界接触圧）

（b）粒子と基材の強度，延性，硬さ

(c) 粒子と基材の酸化物形成と密着

(d) 粒子径

（e）基材表面の前処理

M. F. Smith 博士らが報告したコールドスプレーにおけ る銅粒子がステンレス基材上に衝突した瞬間の計算と実 験の結果を簡単に説明する. $400 \mathrm{~m} / \mathrm{s}$ の衝突では, 基材 に小さなクレーター状のくぼみしかできないが，500， 600， $700 \mathrm{~m} / \mathrm{s}$ と速度を上げると，クレーターと粒子の偏 
平度合いも大きくなる。そして， $600 \mathrm{~m} / \mathrm{s}$ の衝突には， 基材との界面で高速で摩擦し，せん断力が生じるために 発熱（Imapct Heating）して，粒子と基材界面付近は融点 以下ではあるが，最大 $1280 \mathrm{~K}$ 近くまで計算上は達し，か つ基材と粒子の界面部分はマティリアルジェットが発生 していると報告している.よって，界面は酸化などのな い新生面どうしで接触し, その接触圧も高くなるからこ とからかなり強い密着力が得られるとの報告している15, 16). また，粒子と基材の界面において，上述のように界面温 度の急激な上昇により界面近傍の材料が軟化し，互いに 塑性流動となり容易に変形する現象であるせん断不安定 (Shear instability) が断熱的に生じて接合が生じていると の考えもある ${ }^{14,18)}$.

一方，ドイツのハンブルグ国防大の H. Kreye 教授らも, 計算と実験を行いながらコールドスプレー粒子の密着機 構や臨界速度の解釈を同様に行っている14, 17)。 また, 彼ら は銅に対する結果に偏微分によるパラメーターの近似か ら，臨界速度をシンプルな次式にまとめている17).

$V_{c r}=667-14 \rho_{p}+0.08 T_{M P}+0.1 \sigma_{u}-0.4 T_{p i} \cdot$ ・ (1)

ここで， $\rho_{p}$ は粒子密度 $\left(\mathrm{g} / \mathrm{cm}^{3}\right), T_{M P}$ は粒子材料の融 点 $\left({ }^{\circ} \mathrm{C}\right), \sigma_{u}$ は粒子材料の極限強さ $(\mathrm{MPa}), T_{p i}$ は粒子初 期温度 $\left({ }^{\circ} \mathrm{C}\right)$ である.

式 (1) より臨界速度は粒子の融点，極限強さにより大 きくなり，密度および粒子初期温度が高いほど低下する ことになる．銅，アルミニウムに対しておおむね良い一 致を示している。よって，他の材料に対して臨界速度を 推定するとチタンは約 $680 \mathrm{~m} / \mathrm{s}$ と高く，覀鉛は約 $530 \mathrm{~m} / \mathrm{s}$ 低く，一方，アルミニウムは密度が低いため約 $620 \mathrm{~m} / \mathrm{s}$ と高くなる ${ }^{17}$.

しかし，上述のようにこれら以外も基材側の材料特性 や温度，ガンのトラバース速度，基材の表面状態19)，粒子 材料の酸素含有量 ${ }^{20}$ ，化学組成などにも依存することが示 唆されており，さらなる臨界速度の解明が求められてい る.

また，式 (1) の右項の粒子初期温度 $T_{p i}$ を高くすること は臨界速度が低くなり成膜しやすくなる。つまり，コー ルドスプレーといっても，ガス温度を高くしたり，ノズ ル先細部を長くしたりして ${ }^{10}$ 粒子をより加熱した方がより 付着率が上がることがわかる.

T. Schmidt らは，図 7 のコールドスプレーにおける衝 突時の粒子の挙動に及ぼす粒子の温度と速度の関係と図 8 の粒子径の依存性を示した ${ }^{14)}$.すなわち，衝突時の粒子 の速度，温度ともに高すぎても低すぎても付着せず，適 する条件があることを示されている．また，臨界速度に は，上述の粒子のせん断変形に伴い粒径依存性が認めら れ，粒径が小さくなるつれて臨界速度が高くなる．よっ て，衝撃波による粒子衝突速度の低下も含め，コールド スプレーには，材料によって最適な粒子範囲が存在する ことが示唆している.

さらに, 衝突時の粒子と基材の弾性エネルギー $E_{E L}$ と 密着エネルギー $E_{a d}$ との大小により, 密着したり, 跳ね返 る（Rebound）ことの数式化 ${ }^{21,22)}$ 報告されている.

以上のように，密着・臨界速度の理解について，かな り基礎的な研究は進んでいるものの，十分には明らかに
なっていない，基材-粒子間，粒子-粒子間の密着が，単 なるアンカー効果のみなのか, 金属結合しているかなど の機構は, 材料, 衝突速度, 雲囲気などによっても異な るため, 結合のメカニズムも不明確で今後の研究が期待 される．なお，基材と皮膜の密着力は，基材と皮膜の材 料や施工条件により異なるが，概ね $30 \sim 60 \mathrm{MPa}$ 程度であ る.

その他にも，粒子と基材の衝突角度も影響し，垂直か ら $60^{\circ}$ までが付着の限度である8, 23).

\section{4.コールドスプレーの特徵}

コールドスプレーは，粒子を噴射することから，溶射 技術と比較する場合が多く，主たる溶射材料である金属 の融点は, $500^{\circ} \mathrm{C}$ から $1800^{\circ} \mathrm{C}$ 付近にるため, 溶射法では 程度の差はあるが, 溶射粒子の熱変質は避けれらなかっ た。一方，コールドスプレーは，上述のようにノズル入 口部において高々 $500^{\circ} \mathrm{C}$ 程度であり，ノズル末広部では 膨張するため，ガスの静温度は室温以下に下がる.

また，図 1 に示したように使用する粒子径が, 加速と 衝撃波による減速のため, 比較的小さな 5 50 $\mu \mathrm{m}$ 程度で あることも特徴である.

よって, 前述した原理により，各研究者が述べている

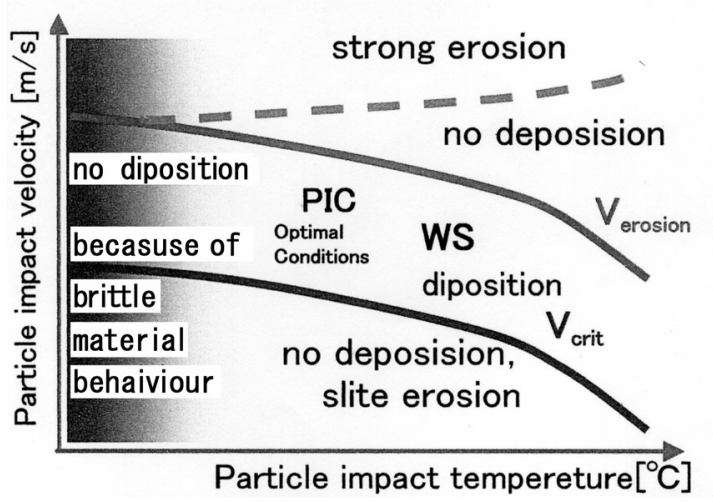

図 7 コールドスプレーにおける衝突時の粒子の挙動 に及ぼす粒子の温度と速度の関係 ${ }^{14)}$

WS: Window of Sprayablity, PIC: Particle Impact Conditions

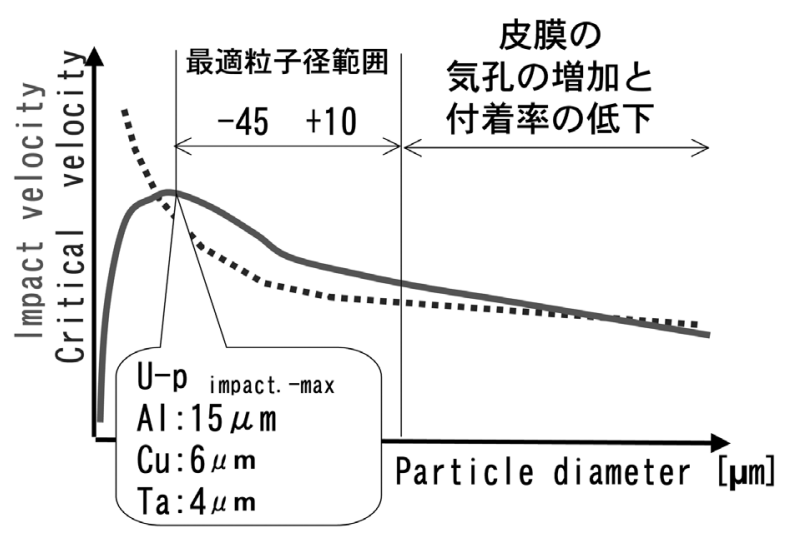

図 8 粒子径に対する粒子の衝突速度と臨界速度の関係 ${ }^{14)}$ 
ことをまめるとコールドスプレーの特徵は以下のように なる。

(1) 溶融や液体から固体への変化の回避 ; 熱応力の除 去，酸化，熱変質の抑制（未成膜粉末の再利用）, 相と組成の安定性，結晶粒の成長がなく，微小結晶 構造の残存が可能

(2) ち密な皮膜

(3) 密度，熱および電気伝導率が高い皮膜

(4) 圧縮性残留応力の皮膜，厚膜が作製可能

(5) 高い付着率（ただし，粉末材料に依存)

(6) 基材への入熱量が抑制

(7) 従来の皮膜より硬度が高い（加工硬化による）

(8) 必要最小限のマスキング (小さな堆積パターン)

(9) 小さい面積にもコーティングが可能（形状に依存す るが $3 \mathrm{~mm}$ 以下も可能)

(10) 基材の形状に依存する

(11) 優れた表面仕上げ加工性

(12)ノズル先端と基材間距離（スプレー距離）が短い (5-30 mm)

(13) 装置が比較的シンプルである.

M. F. Smith 博士は，特徵のはじめに「従来の溶射法に おける溶融と固化に伴う問題が回避できる」と掲げ24)，新 しい溶射法であり，優れていることを強調している.

上記したようにこのプロセスにより作製された皮膜の 最大の特徵は(1)酸化，熱変質がほとんどないことである. さらに，粒子速度が臨界速度以上になるように粒度管理 と作動ガス条件の設定をすれば，80\% 以上の5高い付着 率が得られる場合もあり，ほとんどの報告では粉末材料 にもよるが $60 \%$ 以上の付着率を達成している．また，低 温の不活性な窒素などのガス中を数 $\mathrm{ms}$ の短い滞留時間 で基材に衝突・堆積するため，熱変質しやすい材料粉末 などでも成膜することが可能である．さらに，あまり加 熱できない基材上にも成膜ができる.

一方，欠点としては以下が挙げられる.

（a）基礎的な成膜のメカニズムの理解が不十分

(b) 皮膜特性の解明とそのデータベースが少ない (c) 粉末材料とその施工パラメーターのデータベースや 経験が不十分

(d) 消費ガス量が多い

（e）ノズル内への粒子の堆積（粒子が溶融していないの にノズル内に堆積, 特に，アルミニウムなど低融点 金属)

(f) 使用できる粒子径が比較的細かい（5 $\mu \mathrm{m} \sim 25 \mu \mathrm{m}$ 程 度)

（g）基材上での超音速ガスジェットによる衝撃波の影響 により数 $\mu \mathrm{m}$ 以下の微細粒子が成膜しない

(h) ノズル形状の最適化とノズル形状に依存するため装 置間で差異が生じる

(i) 衝突速度による粒子間の接合状態に差異があり皮膜 特性が異なる（熱処理により膜質の改善が可能. ま た，ヘリウムガスを使用して高速で衝突させた場合 は，良質な膜質が作製可能)

(j) $\phi 1 \mathrm{~mm}$ 程度以下の微細孔内に堆積しにくいなどガ ス流のよどみの影響などを受ける

(k) $1 \mathrm{MPa}$ 以上の高圧ガスを使用する場合は，国内にお いては高圧ガス保安法の適用対象となり，法規制対 象内容（機器，維持管理項目など）の明確化とその 対策

近年，研究開発が盛んになりつつあり，上記の欠点も 克服されつつある。

図 9 に銅とチタンの皮膜断面組織の一例を示す。銅皮 膜は基材側も表面側もち密である。しかし純チタン皮膜 は基材側が幾分ち密であるが表面側に気孔が多い.チ夕 ンは, 結晶構造が最密六方晶構造で変形しにくく, 粒子 径もコールドスプレーにとっては大きく加速が不十分の ため気孔が多い。また，コールドスプレーは高速の粒子 が衝突して成膜していくため，下層の粒子の方がより偏 平する傾向にある.

コールドスプレー皮膜は，高速で衝突・変形による加 工硬化のため材料粉末に比べ硬く，かつばらつきも小さ い.また，コールドスプレーによる銅皮膜の電気伝導度 は純銅の $90 \%$ となり，フレーム溶射や HVOF の銅皮膜は

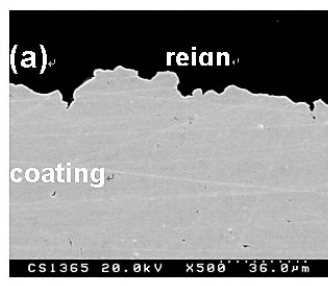

(b)

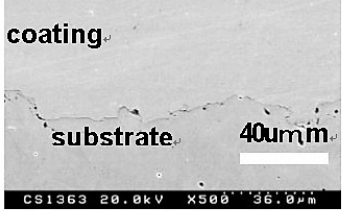

銅皮膜
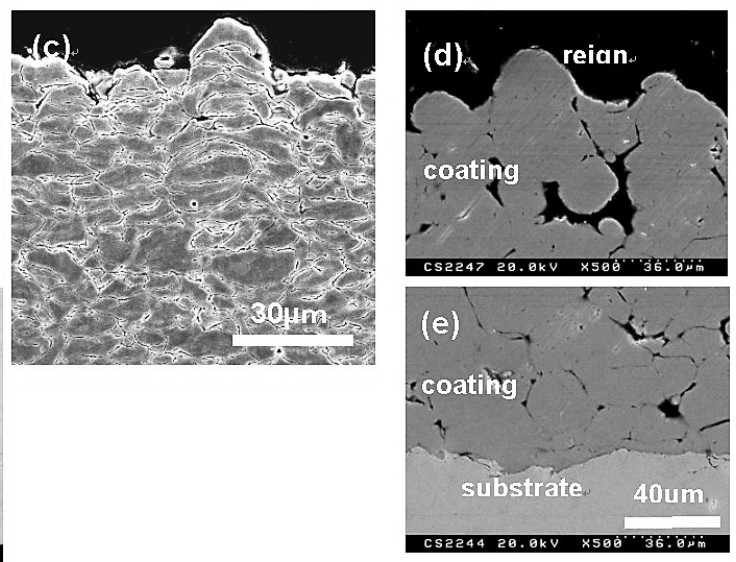

チタン皮膜

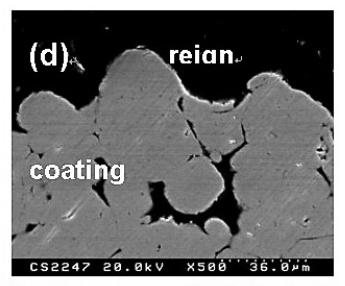

図 9 コールドスプレーによる銅皮膜とチタン皮膜：(純銅 8.2 $\mu \mathrm{m}$, 純チタン

$25 \mu \mathrm{m}$, 窒素ガス, $350^{\circ} \mathrm{C}, 3 \mathrm{MPa}$ ，(a)，(d) は表面側，(b)，(e)は 基材側,（c)は銅皮膜をエッチング） 
50\% 以下との報告もある ${ }^{25)}$.また，(6)基材はガス温度， ガントラバース速度，基材の熱容量などにもよるが，超 音速ガスジェットによる加熱もあり冷却をしない場合は $200^{\circ} \mathrm{C}$ 程度まで上昇する場合もある。しかし，管理をうま くすれば，基材への入熱量を抑えて施工できる.

特徵の (4)に示すように, 皮膜に圧縮性の応力が残り, 皮膜・基材への入熱量が少ないので図10に示すように， 材料にもよるが数 $\mathrm{cm}$ オーダーの厚膜が容易に作製可能 である。

\section{5. コールドスプレーの使用材料}

開発の初期のころは銅，鉄，ニッケル，アルミニウム などの純金属を主体にしていたが，ステンレス鋼，チ夕 ン，モリブデン， $\mathrm{Ni}-\mathrm{Cr}, \mathrm{MCrAlY}$ ，タンタルなどの金属 や合金のほかに，ポリマーならびに $\mathrm{Cr}_{3} \mathrm{C}_{2}-\mathrm{NiCr}$ や WC-Co などのサーメットまでも成膜可能と報告している ${ }^{25}$. 最近 では，一部，チタニアやアルミナなどのセラミックスな ども試みられている。また，熱伝導特性などが良い金属 皮膜が作製できることから，さらなる特性向上を狙い夕゙ イヤモンド， $\mathrm{AlN}, \mathrm{SiC}$ ，タングステンなどを含んだアル
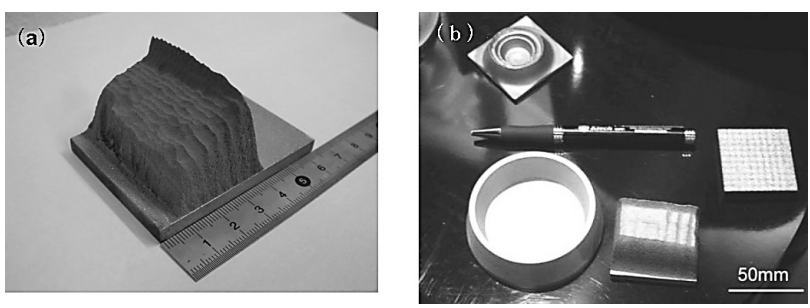

図 10 コールドスプレ - スプレーによる成形体の検討 事例

(a) チタンの厚膜（約 2 分で成形）（信州大）

(b) ITSC2003 にて Kteck 社ブースの展示品

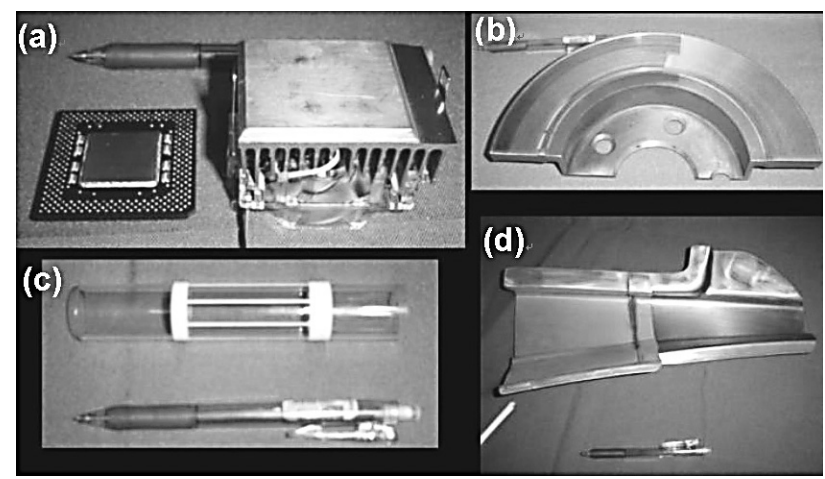

図11 Cold Spray 2004 ワークショップ（2004 年 9 月, アメリカオ八イオ州) の展示会における コールドスプレーの適用検討事例：(a) コンピュ ーター用 CPU ヒートシンクへの銅皮膜の適用 事例，(b) ディスクブレーキへの補修用被覆， (c) プラスチック材上へのアルミニウムスプレ —, (d) 板材接合のためのブレージング材のスプ レ-
ミニウム複合皮膜や銅とタングステン，アルミとアルミ ナ，銅と鉛と錫などの複合皮膜も検討されている.

\section{6. コールドスプレーのアプリケーション 検討事例}

図11に最近のコールドスプレーワークショップの展示 会における適用検討事例を示す。コールドスプレーの商 用レベルでの適用例は少なかったが，2003年あたりから 同図 (a) のコンピューター用 CPU のアルミニウム製ヒー トシンク裏側への銅コーティングが採用され，実用化一 号となった.

公開されたアプリケーションの検討事例まとめると以 下になる ${ }^{6}$.

(a) 自動車用鋼板への亜鉛コーティング

(b) スパッターのターゲット

(c) 大強度加速器施設 中性子線吸収部品への適用（力 ドミウム板へのアルミニウムコーティング）

(d) 金属ニアネットシェイプ部材の作製（Kteck, NASA，ケンブリッジ大など）

(e) コンピューター用 CPU のヒートシンクへの銅皮 (ドイツ OBZ Dresel \& Grasme $\mathrm{GmbH}^{26)}$ )

（f）配線保護金属管接続部への電磁波遮へい用銅皮膜

(g) 溶接部への腐食防止垔鉛皮膜

(h) 各種機械部品の補修

(i) 高温耐食用コーティング（MCrAlY の検討）

(j) ブレージング材の塗布

(k) 医療機器部材への適用（純チタンなど）

(l) マグネシウムの防食用アルミニウム合金皮膜

上述のような優れた特徴をもったコーティング技術で あり，市販装置も販売され，今後多くのが学者や企業が 研究することにより施工条件のデータベースの整理が進 めば，その優れた皮膜特性を望むユーザーから手を伸ば してくることと思う。

国内においては，（財）機械システム振興協会により平 成16年度に調查研究 ${ }^{27)}$, 平成17，18年度にフィージビリテ イスタディビリティスタディ ${ }^{28}$ が産学共同で行われてい る.

\section{7.コールドスプレーの開発動向}

コールドスプレーの基礎的な研究分野では，上述のよ うに粒子の加速や成膜のメカニズム, 臨界速度の理解な どが行われ，応用分野ではさまざまなアプリケーション の開発が行われている.

また，コールドスプレー装置としては，コールドスプ レーで使用する粒径が凡そ5～ $50 \mu \mathrm{m}$ 程度であり，従来の 溶射用の粉末の粒度分布より細かいので市販溶射粉末が 利用できない場合が多い。この欠点を改善した装置が DELPHI 社のキネティックスプレー (Kinetic Spray $\left.{ }^{\circledR}\right)^{29,30}$ がある。一方，ヘリウムによる低圧（0.5 MPa 程度）でガ ス速度を音速程度に止めるガスの消費量が少ないキネテ イックメタライゼーション (Kinetic Metallization $\left.{ }^{\circledR}\right)^{311}$ など もある。 
一方， $1 \mathrm{MPa}$ 以下の圧縮空気をハンディータイプのガ ンで施工できるコールドスプレー装置も開発・市販され,

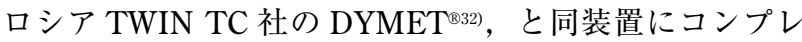
ッサーやタッチパネルなどをつけて操作しやすくしたカ ナダ CenterLine (Windsor) Limited 社の Supersonic Spray Technologies $\left(\mathrm{SST}^{\circledR}\right)^{33}$ がある。空気圧が低圧のため粒子 速度が制限される分を，アルミニウム，銅，亜鉛，ニッ ケルなどの金属粉末にアルミナ砥粒などを加えて，臨界 速度以下でも成膜するように供給粒子に工夫を行ってい る.

\section{8. まとめ}

ロシアでの発見から約 20 年が経とうしている現在， 90 年代から米国，ドイッ，ロシアを中心に研究・開発が進 められてきたため，かなりの開発は進んできた。そのた め，最近は多くの方々に注目されるようなってきたが， 今後さらなる発展のためには，成膜のメカニズムの解明 を含め, 材料科学や圧縮性流体力学などの学際的な研究 を進める必要がある。

\section{参考文献}

1) A. P. Alkimov, A. N. Papyrin, V. F. Kosarev, M. M. Shushpanav: Gas Dynamic Spraying Method for Applying a Coating, U. S. Patent 5, 302, 414, (1994).

2) 例えば, 経済産業省 HP http://www.meti.go.jp/press/20050330012/20050330012.html

3）榊：新しい溶射プロセス Cold Spray，溶射技術，20-2 (2000), 32-41.

4）榊：コールドスプレーテクノロジー，溶射技術，21-3 (2002), 29-38.

5）榊：最新のコーティング技術 コールドスプレー，溶接技 術, 53-10 (2005), 64-71.

6) 榊：コールドスプレーの概要ならびにその軽合金皮膜, 56-7 (2006) 376-385.

7) A. N. Papyrin: Cold Spray Technology, Advanced Materials \& Processes, 159-9 (2001) 49-51.

8) R. C. Dykhuizen, M. F. Smith, D. L. Gilmore, R. A. Neiser, X. Jiang, S. Sampath: Impact of High Velocity Cold Spray Particle, J. of Thermal Spray Technology, 8-4 (1999), 559564.

9) B. Jodin: Cold Spray Nozzle Mach Number Limitation, J. of Thermal Spray Technology, 11-4 (2002), 496-507.

10) K. Sakaki, Y. Shimizu: Effect of Increase in Entrance Length of Gun Nozzle on HVOF and Cold Spray Process, J. of Thermal Spray Technology, 10-3 (2001), 487-496.

11) K. Sakaki, N. Huruhashi, K. Tamaki and Y. Shimizu: Effect of nozzle geometry on cold spray process, Proc. of ITSC2002 (2002), 385-389.

12) H. Liao, W. Y. Li, C. Coddet, et al: Optimal Design of a Convergent-Barrel Cold Spray Nozzle by Numerical Method, Proc. CD-ROM of ITSC2006, (2006)

13）新海，榊ほか：Cold Spray による銅皮膜特性に及ほすす粉末 粒径の影響，日本溶射協会第80回全国講演大会講演 215
(2004), 61-62.

14) T. Schmidt, et al, Development of a generalized parameter window for cold spray deposition, Acta Matelia, 54 (2006), 729-742.

15) R. C. Dykhuizen, M. F. Smith: Gas Dynamic Principles of Cold Gas, J. of Thermal Spray Technology, 7-2 (1998) 205212.

16) D. L. Gilmore, R. C. Dykhuizen, R. A. Neiser, T. J. Romer, M. F. Smith: Particle Velocity and deposition Efficiency in Cold Spray Process, J. Thermal Spray Technology, 8-4 (1999) 576-582.

17) H. Assadi, F. Gartner, T. Stoltenhoff, H. Kreye: Bonding Mechanism in Cold Gas Spraying, Acta Matelia, 51 (2003), 4379-4394.

18) V. K. Chamagne, et al: Interface Material Mixing Formed by the Depisition of Copper on Aluminiumu by Means of the Cold Spray Process, J. Thermal Spray Tech. 14-3 (2005), 330-334.

19) K. Sakaki, T. Tajima, et al: Influence of Substrate Conditions and Traverse Speed on Cold Sprayed Coatings, Proc. CDROM of ITSC2004, (2004).

20) C. -J. Li and W. -Y. Li, Xi' an/PRC: Examination of the critical velocity for deposition of particles in cold spraying, Proc. CD-ROM of ITSC2005 (2005).

21) A. Papyrin, S. V. Klinkov, V. F. Kosarev: Modeling of Particle-Substrate Adhesive Interaction Under the Cold Spray Process, Proc. of ITSC2003, (2003), 27-35.

22) Jingwei $\mathrm{Wu}$, et al: Rebound Phenomenon in $\mathrm{Al}$ alloy Kinetic Spraying, Proc. of $20^{\text {th }}$ Thermal Spray Workshop in Korea Thermal Spray Society, (2004), 107-126.

23) C. -J. Li, W. -Y. Li, Y. -Y. Wang, H. Fukanuma: Effect of Spray Angle on Deposition Characteristics in Cold Spraying, Proc. of ITSC2003, (2003), 91-96.

24) http://www.sandia.gov/Cold Spray/presentations/cs_overview_mfs_90714.pdf.

25) News from Institutes and Research Center around the World, GTS Advances on Cold Spray Technology, J. of Thermal Spray Technology, 10-3 (2001), 434-436.

26) ドイツ OBZ Dresel \& Grasme GmbH カタログまたは http://www.obz-gmbh.de/

27）システム技術開発調査研究 16-R-17 高速粒子衝突を利用し た革新的部材創生に関する調查研究報告，機械システム振 興協会, (2005).

28） システム技術開発調査研究 17-F-11コールドスプレーによ る革新的部材創生に関するフィージビリティスタディビリ ティスタデイ報告書，機械システム振興協会，(2006).

29) T. Van Steenkiste and D. W. Gorkiewicz, Evauation of Coating Produceed via Kinetic and Cold Spray Process: J. of Thermal Spray Technology, 13-2 (2004), 274-282.

30) Van Steenkiste, T. H., Smith, J. R., and R. E. Teets," Aluminum coatings via kinetic spray with relatively large powder particles, Surface \& coatings technology, 111 (1999), 62-71.

31) Kinetic Metallization http://www.inovati.com/pages/products/cds-equip/cds.html

32） TWIN TC 社カタログ DYMET ${ }^{\circledR}$ : http://www.amazonit.ru/ocpn/eindex.html

33） カナダ Centerline LTD. SST カタログまたは $\mathrm{http}: / /$ www.supersonicspray.com/ 